\title{
THE EFFECT OF PARAGENETIC FACTORS ON REPRODUCTIVE TRAITS OF SIMMENTAL COWS**
}

\author{
M. D. Petrovic ${ }^{1 *}$, Z. Skalicki ${ }^{2}$, V. Bogdanovic ${ }^{2}$, M. M. Petrovic ${ }^{3}$ \\ ${ }^{1}$ Faculty of Agronomy, Cacak, ${ }^{2}$ Faculty of Agriculture, Zemun-Belgrade, ${ }^{3}$ Institute for Animal \\ Husbandry, Zemun-Belgrade, Serbia \\ *Corresponding author: e-mail: petrovicm@tfc.kg.ac.yu \\ ** Original scientific paper, supported by the Ministry of Science of the Republic of Serbia, \\ Project No. TR6858
}

\begin{abstract}
The examination was made on the effect of systematic factors (parturition group, calving season, birth type, calf gender, and birth type-calf gender interaction) and age at first conception on the expression of reproductive traits (gestation length, service period, fertility intensity and calf birth weight) in 143 Simmental cows. The overall mean $(\mu)$ for gestation length, service period, intercalving period and calf birth weight was 284.14 days, 153.82 days, 416.92 days and $35.40 \mathrm{~kg}$, respectively. The parturition group effect on all fertility traits was highly significant $(\mathrm{P}<0.01)$. The calving season statistically significantly $(\mathrm{P}<0.05)$ affected the intercalving period and calf birth weight. Birth type induced very significantly longer gestation $(\mathrm{P}<0.01)$ and higher calf birth weight in singles $(\mathrm{P}<0.01)$ and significantly longer service period in twins $(\mathrm{P}<0.05)$. Calf gender had a very significant effect $(\mathrm{P}<0.01)$ only on calf birth weight, and the interaction between birth type and calf gender significantly affected gestation duration only $(\mathrm{P}<0.05)$. The regression effect of age at first conception on all fertility traits was not significant $(\mathrm{P}>0.05)$.
\end{abstract}

Key words: parturition, calving season, calf gender, birth type, age at conception.

\section{Introduction and Literature Review}

In order to accurately assess the breeding value of certain individual cows in a population, it is necessary to examine the paragenetic factors affecting variability of phenotypic values, namely, of reproductive traits. The factors include, among others, calving sequence, calving season, calf gender, birth type and age at first conception.

The effect of paragenetic factors on the expression of reproductive traits 
was investigated by Skalicki (1983), Burfening et al. (1987), Fis and Wilton (1989), Perisic (1998 and 2002), Strapak et al. (2000), Djurdjevic (2001), Bakir et al. (2004), Petrovic D.M. et al. (2004), Pantelic et al. (2005) who concluded that the systematic effects significantly affected the phenotypic value of reproductive traits. The aim of the paper was to assess the factors affecting reproductive trait variability by analysing data on Simmental cows.

\section{Material and Method}

The effect of paragenetic factors on reproductive traits was investigated in 143 Simmental cows housed at the "Zlatiborski Suvati" (Zlatibor Pastures) farm having a loose housing system and lying boxes.

Examinations were made on the effect of systematic factors (parturition group, calving season, birth type, calf gender and birth type-calf gender interaction) and the regression effect of the age at first conception on the expression of reproductive traits such as gestation length (GL), service period (SP), intercalving period (IP) and calf birth weight (CBW).

Mathematical-statistical data analysis or all the values required (least squares means, standard mean errors and significance of the systematic effects examined) were calculated using the following models:

Model 1. Examination of the effect of the said factors on gestation length, intercalving period and calf birth weight:

$$
y_{i j k l m}=\mu+P_{i}+S_{j}+T_{k}+G_{l}+T G_{k l}+b_{1}\left(x_{1}-\bar{x}_{1}\right)+e_{i j k l m}
$$

where: $y_{i j k l m}-$ an individual of the i-th parturition, $\mathrm{j}$-th season, $\mathrm{k}$-th birth type and 1-th gender, $\boldsymbol{\mu}$ - the overall mean at equal distribution of all groups of effects $(P, S, T, G, T G), \boldsymbol{P}_{\boldsymbol{i}}-$ a fixed effect of the i-th parturition group (1-7), $\boldsymbol{S}_{\boldsymbol{j}^{-}}$a fixed effect of j-th season of calving (1-4), $\boldsymbol{T}_{\boldsymbol{k}}-$ a fixed effect of the k-th type of birth (1-2), $\boldsymbol{G}_{\boldsymbol{l}}$ - a fixed effect of the 1-th calf gender (1-2), $\boldsymbol{T}_{\boldsymbol{k} \boldsymbol{l}}-\mathrm{a}$ fixed effect of the interaction between the $\mathrm{k}$-th type of birth and 1-th calf gender (1-4), $\boldsymbol{b}_{\boldsymbol{1}}$ - a linear regression coefficient of the effect of age at first conception, and $\boldsymbol{e}_{i j k l m}-$ other undetermined effects.

Model 2. - Examination of the effect of the said factors on the service period:

$$
y_{i j}=\mu+P_{i}+S_{j}+b_{1}\left(x_{1}-\bar{x}_{1}\right)+e_{i j}
$$

where: $y_{i j}-$ an individual of the $\mathrm{i}$-th lactation and $\mathrm{j}$-th season, $\boldsymbol{\mu}$ - the overall 
mean of the population at equal distribution of all groups of effects (P, S), $\boldsymbol{P}_{\boldsymbol{i}}$ - a fixed effect of the i-th parturition group (1-7), $\boldsymbol{S}_{j}$ - a fixed effect of the jth season (1-4), $\boldsymbol{b}_{1}-$ a linear regression coefficient of the effect of age at first conception, and $\boldsymbol{e}_{i j}-$ other undetermined effects.

\section{Results and Discussion}

Table 1 presents the overall mean $(\mu)$, least square means (LSM) and standard error of the least square means $\left(\mathrm{SE}_{\mathrm{LSM}}\right)$ for the reproductive traits corrected for the effect of systematic factors.

The overall mean of the least square means corrected for the effect of the systematic factors examined (parturition group, calving season, birth type, calf gender and gender-type interaction) was 284.14 days for gestation length, 153.82 days for the service period, 416.92 days for the intercalving period and $35.40 \mathrm{~kg}$ for calf birth weight.

The effect of parturition (parturition group) on the gestation length caused differences in gestation duration which were statistically very highly significant $(\mathrm{P}<0.001)$. Namely, with the ageing of the cows, gestation length increased, the first gestation being the shortest, which was obvious bearing in mind the inadequate cow development, and the sixth parturition group having the longest gestation, which was 1.78 days longer than the overall mean. The calving season did not induce statistically significant differences in gestation duration, due to the fact that the trait examined was more biologically determined and less susceptible to variations under the effect of paragenetic factors.

Birth type caused statistically very significant differences $(\mathrm{P}<0.01)$ in the duration of gestation, which was 1.73 days shorter than the overall mean in twins and 1.72 days longer in singles. Calf gender did not bring about statistically significant differences $(\mathrm{P}>0.05)$ in gestation duration although gestation was somewhat shorter in male calves, whereas the interaction between calf gender and birth type induced significant differences $(\mathrm{P}<0.05)$ in gestation length, which was in accordance with the results obtained by Skalicki (1983).

The effect of parturition on the service period duration was very significant $(\mathrm{P}<0.01)$. The service period after the first calving lasted considerably longer than the period after the second and third calvings when it was the shortest. This was due to the fact that the growth of the cows after the first parturition was not yet completed, meaning that a portion of their 
feed, at the time of intensive milk production, which was generally not included in the meal, was required for growth as well, which led to estrus delay, conception success rate decrease and prolonged first service period.

Table 1. Least square means for the reproductive traits of cows

\begin{tabular}{|c|c|c|c|c|c|c|c|c|}
\hline \multirow{3}{*}{$\frac{}{\text { Overall mean }(\mu)}$} & \multirow{2}{*}{\multicolumn{2}{|c|}{$\begin{array}{c}\mathbf{G L} \\
\text { (days) }\end{array}$}} & \multirow{2}{*}{\multicolumn{2}{|c|}{\begin{tabular}{|c|} 
SP \\
(days)
\end{tabular}}} & \multirow{2}{*}{\multicolumn{2}{|c|}{$\begin{array}{c}\begin{array}{c}\text { IP } \\
\text { (days) }\end{array} \\
\mathbf{4 1 6 . 9 2} \\
\end{array}$}} & \multirow{2}{*}{\multicolumn{2}{|c|}{$\begin{array}{c}\begin{array}{c}\mathbf{B C W} \\
(\mathrm{kg})\end{array} \\
\mathbf{3 5 . 4 0}\end{array}$}} \\
\hline & & & & & & & & \\
\hline & LSM & $\mathbf{S E}_{\text {LSM }}$ & LSM & $\mathbf{S E}_{\text {LSM }}$ & LSM & $\mathbf{S E}_{\text {LSM }}$ & LSM & $\mathbf{S E}_{\text {LSM }}$ \\
\hline I (1) & 281.02 & 1.04 & 158.56 & 12.51 & - & - & 32.99 & 0.62 \\
\hline II (2) & 283.43 & 1.01 & 136.97 & 12.02 & 424.23 & 11.49 & 35.33 & 0.60 \\
\hline III (3) & 284.59 & 0.99 & 132.83 & 11.96 & 403.89 & 11.29 & 34.79 & 0.59 \\
\hline IV (4) & 284.36 & 1.01 & 153.92 & 12.44 & 396.23 & 11.54 & 36.34 & 0.60 \\
\hline $\mathrm{V}(5)$ & 284.84 & 1.08 & 177.43 & 13.71 & 422.92 & 12.33 & 36.02 & 0.64 \\
\hline $\mathrm{VI}(6+7)$ & 285.92 & 1.01 & 157.93 & 13.19 & 435.24 & 11.52 & 35.99 & 0.60 \\
\hline $\mathrm{VII}(8+9+10+11)$ & 284.80 & 1.21 & 159.07 & 17.40 & 418.98 & 13.85 & 36.35 & 0.72 \\
\hline Fexp & \multicolumn{2}{|c|}{$5.54^{* *}$} & \multicolumn{2}{|c|}{$3.42^{* *}$} & \multicolumn{2}{|c|}{$4.46^{* *}$} & \multicolumn{2}{|c|}{$8.56^{* *}$} \\
\hline \multicolumn{9}{|l|}{ Season } \\
\hline I & 284.34 & 0.93 & 157.22 & 11.42 & 407.58 & 10.82 & 35.08 & 0.55 \\
\hline II & 283.35 & 0.95 & 145.20 & 11.68 & 411.90 & 11.10 & 35.94 & 0.56 \\
\hline III & 283.86 & 1.00 & 163.71 & 12.54 & 437.02 & 11.55 & 34.89 & 0.59 \\
\hline IV & 285.00 & 0.93 & 149.14 & 11.46 & 411.16 & 10.90 & 35.71 & 0.55 \\
\hline Fexp & \multicolumn{2}{|c|}{$2.20^{N S}$} & \multicolumn{2}{|c|}{$1.66^{N S}$} & \multicolumn{2}{|c|}{$3.62^{*}$} & \multicolumn{2}{|c|}{$2.65^{*}$} \\
\hline \multicolumn{9}{|l|}{ Type } \\
\hline I & 285.86 & 0.26 & 133.49 & 3.56 & 418.70 & 3.24 & 38.84 & 0.15 \\
\hline II & 282.41 & 1.67 & 174.14 & 20.41 & 415.14 & 19.10 & 31.96 & 0.99 \\
\hline Fexp & 10. & & & & 0.5 & & & \\
\hline Gender & & & & & & & & \\
\hline I & 282.96 & 0.86 & 147.58 & 12.14 & 406.06 & 9.92 & 36.46 & 0.51 \\
\hline II & 285.31 & 1.46 & 160.06 & 16.82 & 427.77 & 16.67 & 34.34 & 0.86 \\
\hline Fexp & 2.2 & & & & 1.6 & & & \\
\hline Type Gender & & & & & & & & \\
\hline I & 286.30 & 0.36 & 130.76 & 4.73 & 414.92 & 4.50 & 40.14 & 0.21 \\
\hline II & 285.42 & 0.36 & 136.22 & 4.73 & 422.47 & 4.47 & 37.55 & 0.21 \\
\hline II & 279.62 & 1.68 & 164.39 & 23.66 & 397.20 & 19.21 & 32.79 & 1.00 \\
\hline II & 285.20 & 2.89 & 183.89 & 33.29 & 433.07 & 33.02 & 31.14 & 1.71 \\
\hline Fexp & 3. & & & & & & & \\
\hline
\end{tabular}


After the fourth parturition, the service period duration increased to be the highest after the fifth parturition, but after the following ones its length was recorded to be at the first service period level. Different significances of the effect of lactation and calving sequence were obtained by Skalicki (1983), Perisic (1998) and Pantelic et al. (2005). On the other hand, calving season did not statistically significantly affect $(\mathrm{P}>0.05)$ the service period duration.

The birth type effect on the service period duration was statistically significant $(\mathrm{P}<0.05)$. The cow service period after twin calving was about 20 days longer than the overall mean, which was due to delayed estrus induced by greater exhaustion of cows after twin calving, which was in accordance with the investigations by Perisic (1998). Calf gender and the interaction between birth type and calf gender did not statistically significantly affect $(\mathrm{P}>0.05)$ the service period duration.

The intercalving period, as is the case with the service period, was considerably more susceptible to the effect of paragenetic factors. The parturition effect on the intercalving period length was statistically very highly significant $(\mathrm{P}<0.001)$. The intercalving period length statistically significantly differed $(\mathrm{P}<0.05)$ by calving seasons and was the greatest in the autumn season (437.02 days) and the shortest in the summer season where it was 407.58 days. Birth type, calf gender and the interaction between birth type and calf gender did not statistically significantly affect $(\mathrm{P}>0.05)$ the duration of the intercalving period.

The most pronounced effect by the paragenetic factors examined was exerted on the calf birth weight. With the ageing of the cows, an oscillatory increase in calf weight was registered, the lowest weight being in the first calving, $32.99 \mathrm{~kg}$, due to inadequate cow development, and the greatest weight, $36.35 \mathrm{~kg}$, being recorded with the seventh parturition group made up of cows with the eighth, ninth, tenth and eleventh parturitions. The differences between calf weights by parturition groups were statistically very highly significant $(\mathrm{P}<0.001)$.

Calf weights statistically significantly differed $(\mathrm{P}<0.05)$ by seasons. The heaviest calves were registered in the summer season, where their weight was $0.54 \mathrm{~kg}$ higher than the mean, and the lightest ones in the autumn season, where their weight was $0.51 \mathrm{~kg}$ lower than the overall mean. With respect to the effect of the interaction between mother's age and calving season Burfening et al. (1987), concluded that the differences between the calves born in spring and those born in autumn were higher in older than in younger cows and were statistically significant $(\mathrm{P}<0.05)$. 
The birth type and calf gender effects on the calf birth weight were statistically very highly significant $(\mathrm{P}<0.001)$. Namely, the twins were lighter and the singles were heavier than the overall mean by $3.44 \mathrm{~kg}$, and male calves were heavier and female ones lighter than the overall mean by $1.06 \mathrm{~kg}$.

The interaction between birth type and calf gender did not significantly affect $(\mathrm{P}>0.05)$ calf birth weight.

The results on the regression analysis of the effect of age at first conception on reproductive traits after models 1 and 2 are presented in table 2.

Table 2. Regression analysis of the effect of age at first conception on reproductive traits of cows following the general linear model.

\begin{tabular}{|c|c|c|c|c|}
\hline & $\begin{array}{c}\mathbf{G L} \\
\text { (days) }\end{array}$ & $\begin{array}{c}\mathbf{S P} \\
\text { (days) }\end{array}$ & $\begin{array}{c}\mathbf{I P} \\
\text { (days) }\end{array}$ & $\begin{array}{l}\mathbf{C B W} \\
\text { (days) }\end{array}$ \\
\hline $\mathrm{a}$ & $288.532^{* *}$ & $156.962^{* *}$ & $393.456^{* *}$ & $31.118^{* * *}$ \\
\hline Age at $1^{\text {st }}$ concep.- $b_{x y}$ & $-0.003^{\mathrm{NS}}$ & $0.048^{\mathrm{NS}}$ & $0.062^{\mathrm{NS}}$ & $0.002^{\mathrm{NS}}$ \\
\hline Regression equations & $=288.53-0.0$ & $156.96+0$. & $393.46+0.0$ & $=31.12+0.002 x$ \\
\hline
\end{tabular}

The effect of age at first conception on reproductive traits, as seen from the linear regression coefficients presented in the table, was not statistically significant $(\mathrm{P}>0.05)$.

\section{Conclusion}

Based on the results presented, it can be concluded that the overall mean $(\mu)$ for gestation length, service period, intercalving period and calf birth weight was 284.14 days, 153.82 days, 416.92 and $35.40 \mathrm{~kg}$, respectively. The parturition group effect on all fertility traits was highly significant $(\mathrm{P}<0.01)$. The calving season statistically significantly $(\mathrm{P}<0.05)$ affected the inercalving period and calf birth weight, whereas it did not significantly affect gestation length and service period $(\mathrm{P}>0.05)$. Birth type induced very significantly longer gestation $(\mathrm{P}<0.01)$ and greater calf birth weight in singles $(\mathrm{P}<0.01)$, considerably longer service period in twins $(\mathrm{P}<0.05)$ but it did not have any significant effect on the intercalving period $(\mathrm{P}>0.05)$. Male calf weight was very significantly $(\mathrm{P}<0.01)$ higher than female calf weight and calf gender did not significantly affect $(\mathrm{P}>0.05)$ gestation length, service period and fertility intensity. The interaction between birth type and calf 
gender significantly affected gestation duration only $(\mathrm{P}<0.05)$. The regression effect of the age at first conception on all fertility traits was insignificant $(\mathrm{P}>0.05)$.

\title{
UTICAJ PARAGENETSKIH FAKTORA NA REPRODUKTIVNE OSOBINE KRAVA SIMENTALSKE RASE
}

\author{
M.D. Petrović, Z. Skalicki, V. Bogdanović, M.M. Petrović
}

\section{Rezime}

$\mathrm{Na}$ ispoljenost reproduktivnih osobina (dužina bremenitosti, servis period, intenzitet plodnosti i masa teladi pri rođenju) kod 143 krave simentalske rase, ispitivan je uticaj sistematskih faktora (grupe partusa, sezone telenja, tip rođenja, pol teladi i interakcija tipa rođenja i pola teladi) i uzrasta pri prvoj oplodnji. Opšti prosek $(\mu)$ za dužinu bremenitosti iznosio je 284.14 dana, servis period 153.82 dana, međutelidbeni interval 416.92 i masu teladi pri rođenju $35.40 \mathrm{~kg}$. Uticaj grupe partusa na sve osobine plodnosti bio je visoko značajan $(\mathrm{P}<0.01)$. Sezona telenja statistički značajno $(\mathrm{P}<0.05)$ je uticala na međutelidbeni interval i masu teladi pri rođenju. Tip rođenja uslovio je vrlo značajno dužu bremenitost $(\mathrm{P}<0.01)$ i veću masu teladi pri rođenju kod jedinaca $(\mathrm{P}<0.01)$ i značajno duži servis period kod blizanaca $(\mathrm{P}<0.05)$. Pol teladi vrlo značajno je uticao $(\mathrm{P}<0.01)$ samo na masu teladi pri rođenju, dok je interakcija tipa rođenja i pola teladi značajno uticala samo na trajanje bremenitosti $(\mathrm{P}<0.05)$. Regresijski uticaj uzrasta pri prvoj oplodnji na sve osobine plodnosti nije bio signifikantan $(\mathrm{P}>0.05)$.

Ključne reči: partus, sezona telenja, pol teladi, tip rođenja, uzrast pri oplodnji.

\section{References}

BAKIR G., KAYGISIZ A., ÜLKER H.(2004): Estimates of Genetic and Phenotypic for Birth Weight in Holstein Friesian Cattle. Pakistan Journal of Biological Sciences 7 (7): 1221-1224, 2004.

BURFENING J.P., KRESS D.D., HANFORD K.(1987): Effect of region of the United States and age of dam on birth weight and 205-d weight of simmental 
calves. Journal of Animal Science, Vol. 64, Num. 4, 955-962.

ĐURĐEVIĆ R. (2001): Genetička analiza mlečnosti i reprodukcijskih svojstava krava simentalske rase. Doktorska disertacija. Poljoprivredni fakultet Novi Sad, 2001.

FISS F.C., WILTON J.W.(1989): Effects of breeding system, cow weight and milk yield on reproductive performance in beef cattle. Journal of Animal Science, Vol. 67, Num. 7, 1714-1721.

PANTELIĆ V., SKALICKI Z., LATINOVIĆ D., PETROVIĆ M.M., KUČEVIĆ D.(2005): Ispitivanje dejstva pojedinih paragenetskih faktora na osobine plodnosti bikovskih majki simentalske rase. Biotehnologija u stočarstvu, vol. 21 (3-4), str. 35-41, 2005.

PERIŠIĆ P. (1998): Reproduktivne i proizvodne osobine različitih genotipova krava simentalske rase. Magistarska teza, Poljoprivredni fakultet, BeogradZemun.

PERIŠIĆ P., SKALICKI Z., PETROVIĆ M.M., MEKIĆ C., ĐEDOVIĆ-VIDIĆ R. (2002): Uticaj uzrasta pri prvoj oplodnji na proizvodne osobine krava simentalske rase. Savremena poljoprivreda, vol. 51, 3-4(2002), str.97-99, Novi Sad.

PETROVIĆ D.M., GUTIĆ M., BOGOSAVLJEVIĆ-BOŠKOVIĆ S. (2004): Masa teladi pri rođenju i njena varijabilnost kod krava simentalske rase. Agroznanje, vol., 5., br. 1. 2004, 111-116. Banja Luka.

SKALICKI Z.(1983): Fenotipska varjabilnost i povezanost reproduktivnih i proizvodnih osobina austrijskog i nemačkog simentalca (magistarska teza). Univerzitet u Beogradu, Poljoprivredni fakultet.

STRAPAK P., VAVRISINOVA K., CANDRAK J., BULLA J. (2000): Calving ease and birth weight of calves of Slovak Simmental cows. Czech Journal of Animal Science. 2000, 45: 7, 293-299; 15 ref. 